Indonesian Journal of EFL and Linguistics

Vol. 5 No. 1,2020

eISSN: 2503-4197, pISSN: 2527-5070

www. indonesian-efl-journal.org

\title{
Cohesion and Coherence of Discourse in the Story of "Layangan Putus" on Social Media Facebook
}

\author{
Ani Latifah \\ Yogyakarta State University \\ ani.latifah27@gmail.com \\ Sulis Triyono \\ Yogyakarta State University \\ sulis@uny.ac.id
}

\begin{abstract}
:
This research is to find out how the use of cohesion and coherence in the story of "Layangan Putus", which was viral some time ago. Because cohesion and coherence are important criteria and principles in a text. This research is expected to contribute to the development of the quality of story writing. So the story can be understood and useful for the readers. Thus, the purpose of writing stories can inspire readers. The method used to analyze cohesion and coherence was a descriptive analysis seen in each paragraph. The cohesion aspects analyzed were lexical and grammatical cohesion aspects. The results of this study indicated that the story of "Layangan Putus" had aspects of lexical cohesion, grammatical cohesion, and coherence. Aspects of cohesion and constructive coherence in which discourse can convey a message to readers. In this way, the contents of the story can make the reader into feeling what the writer feel.
\end{abstract}

Keywords: Cohesion and Coherence, Discourse, Layangan Putus 
Ani Latifah \& Sulis Triyono

\section{INTRODUCTION}

Language is used in every daily human activity which certainly has a close relationship with social phenomena. Language is used as a tool to convey one's thoughts and feelings to others. Every person has a different background, thus, in conveying one's thoughts or ideas must use different or varied languages. Because the differences in the background include differences in educational backgrounds, the origin of residence, work, age, social experience and so forth. That background affects the success of communication.

Communication can use spoken or written language, one example of written language is discourse. Discourse is the most comprehensive set of languages in the form of a series of related, cohesive, and coherent sentences in accordance with the context of the situation, thus forming a single unit of information. Information in a discourse is demanded to have the integrity of the discourse structure. The presence of cohesion and coherence is very important so that a discourse can be understood easily.

Research about cohesion and coherence has indeed been done a lot, but there are still many people who have not yet understood the essence of cohesion and coherence from a text or discourse. Among the studies conducted by Andayani (2014) examined about Cohesion and Coherence of the Students' Narrative Writings in SMP Negeri 2 Banjar, the results of the study stated that there were still many students who did not understand the meaning of cohesion and coherence, based on data, the type of cohesion that often arises was conjunction.

Another study conducted by Prayudha (2016) examined Cohesion and Coherence of Editorial in the Jakarta Post and Widiatmoko (2015) who examined Cohesion and Coherence of National Rubric News Discourse in Detik Online Magazine. Both of these studies found that all types of cohesion and coherence devices were found in the print media. Among them were references, ellipsis, substitution, and conjunction. But among the types of cohesion and coherence that appeared uneven so that the linguistic aspects of the two print media were still lacking.

In addition to conjunction, collocation and synonyms are also one of the discussions in the cohesion and coherence of discourse. As a study conducted by Aghdam and Hadidi (2015) who examined the Cohesion and Coherence in Political Newspapers and Discussion Sections of Academic Articles. Based on research that has been done, it showed that synonym was one of the aspects that stands out in large numbers in a discourse. Another important finding was the existence of words that were not identical and collocational. In academic articles, the frequency and percentage of synonym words were higher than collocational words. Whereas in the news genre, the frequency and percentage of collocational words were higher than synonym words. 
Analyzing cohesion and coherence in newspapers, magazines, especially those relating to political news is still a favorite topic of discussion within the scope of discourse analysis. For example in analyzing the function of text in discourse will certainly use cohesion and coherence tools. As research by Mubarak (2014) who analyzed the cohesion contained in the political news published by the Jakarta Post showed that the newspaper has a good cohesive tool in every paragraph. In this research, the cohesion device becomes an instrument in summarizing the results of the study.

Research on the current discourse draws heavily on what is happening in social media. Information, writing, can easily be accessed by everyone, and also easily become viral quickly. What we write, can quickly give us a lot of praise or blasphemy from people who read. However, there are some people who also deliberately write extreme information content with the aim of making themselves to be famous, even though they are known for things that are not good, because popularity is the main goal.

Some of the research above examined discourse in print media. In the current era, where technological developments are increasingly sophisticated, it is rare for people to do written communication using letters or writing in a diary. People usually express their problems or happiness through social media such as Facebook, Twitter, and other social media. As happened a few moments ago where there was a woman with a Facebook account by "Mommi Asf". She told about the betrayal of her husband who was tempted by another woman and ended in divorce in her Facebook account. The story made Eve who commented on Mommi Asf's account felt sympathy and immediately became a trending topic on Facebook and Twitter.

The matter like that is easy to happen because Facebook is one of the media that can be accessed by everyone. Whatever we write and distribute on Facebook will be easily read by other people or Facebook users. So, we must be wiser and more careful in writing and disseminating information on social media. Because, if we don't sort out the content that we will write and spread, it will have good or bad effects. Facebook users come from various backgrounds with a variety of different backgrounds, so it is also different in the use and meaning of the language. The marker is found with variations in the use of cohesion and coherence and its role in discourse. Because of these problems, it is interesting to study, used as material for learning the elements of cohesion and coherence in discourse. Based on this background, research needs to be done about "Cohesion and Coherence of Discourse in the Story of "Layangan Putus" on Social Media Facebook".

\section{LITERATURE REVIEW}

\subsection{Discourse}

Indonesian Journal of EFL and Linguistics, 5(1), 2020 
Discourse is the most complete language unit and is the highest or largest grammatical unit in the grammatical hierarchy. However, the realization of discourse can be in the form of a complete essay (whole, books, encyclopedia series, etc.), paragraphs, sentences, phrases, even words that carry the full mandate (Kridalaksana: 2008).

Meanwhile, Alwi (2003: 419) discourse is a series of related sentences that connect one proposition with another proposition that forms a unity. Here the discourse is illustrated by sentences arranged sequentially in one meaning. The sentences arranged are interrelated to each other so that the fourth sentence may not be clear meaning if there is no third sentence, the third sentence may not be clear meaning if there is no second sentence and so on.

Unlike with others, Eriyanto (2001: 9) defines Discourse as a text and context together. The focus of discourse analysis is to describe the text and context together in a communication process. Eriyanto also argues about the importance of the elements of discourse, namely context, participants, intertext, and situation. Discourse is a form of practice social, as a form of applying the dialect relationship between real events and institutions with the social structure that occurs.

Moeliono (2004: 96) requires a good and complete discourse by having cohesive sentences as a cohesive form that structurally forms the syntactic bond of the sentence. So to compose a discourse must have a coherent and complete connection that is cohesive and coherensive sentences. While Louise (2007: 214) defines discourse as a language user in everyday speech and text, a dynamic form of social practice that constructs the social world, identity, and individual self.

A discourse is a language unit that is bound by a unity. Unity can be seen in terms of form and terms of meaning. Therefore, discourse is always realized in the form of a series of sentences. A discourse can be found in the form of a sentence, it can even be in the form of a phrase or word. In other words, discourse is a series of interlocking sentences so that a harmonious meaning is formed between the sentences (Alwi, et al. 2003: 43).

From this explanation, it can be seen that discourse is a unit the most complete element of language, composed of sentences, both oral and written that form a harmonious and integrated understanding, both in terms of and in their phonetic manifestations, because discourse is demanded to have structural integrity. Wholeness itself is built by the components that are intertwined in an organization of discourse. This organization is called the discourse structure. As an organization, the structure of discourse can be decomposed or described its parts (Mulyana, 2005: 25).

The integrity of the structure of discourse is closer to its meaning as a meaningful (semantic) unity than as a form of syntax (Halliday and Hassan, 1976: 2). A series of 
sentences is said to be the structure of discourse if there is an emotional (meaningful) relationship between one part and another. Conversely, a series of sentences may not be referred to as discourse if each sentence in the series has its own meaning and is not related semantically.

A good discourse consists of a series of sentences that have aspects that are related to meaning, between one sentence linked to the meaning of another sentence from the beginning until the end. These aspects include cohesion, coherence, discourse topics, lexical aspects, grammatical aspects, phonological aspects, and semantic aspects (Halliday \& Hasan: 1976; Richards: 2002; Moeliono: 2004). Discourse integrity is also supported by the setting or context of the discourse. Comprehensively it can be said that the integrity of discourse can occur from the interrelation between two main aspects of discourse, namely text, and context (Alwi: 2003).

Some aspects of the discourse mentioned above can be grouped into two elements, namely cohesion, and coherence. The Cohesion element includes lexical, grammatical, phonological aspects, while the coherence element covers the semantic aspect and the generalization aspect, where cohesion and coherence are almost the same because some signs of cohesion aspects are also signs of coherence aspects, but it is still possible to distinguish them (Mulyana, 2005: 36).

\subsection{Cohesion}

An article can be said to be easy to read and understand if it has neat form and cohesiveness of meaning. Tarigan gives the definition of cohesion, which is the aspect of form that refers to the formal aspect of language namely how propositions relate to each other to form a text. It means that cohesion is a syntactic organization where sentences are arranged in an integrated manner to produce discourse, both in terms of grammatical levels and certain lexical levels.

The concept of cohesion basically refers to the relationship of forms. Meaning, the discourse elements (words or sentences) used to arrange a discourse have a coherent and complete connection. In other words, cohesion is included in the internal aspects of the structure of discourse. In this connection, Halliday (1976) suggests that research on the elements of cohesion becomes part of the study of formal aspects of language. Therefore, the organization and structure of discourse is also concentrated and syntactic-grammatical in nature.

According to Moeliono (2004: 34), to get a good and complete discourse, the sentences must be cohesive. Only with such a cohesive like that, the element of discourse can be interpreted, according to its dependence on other elements. Cohesion allows the establishment of semantic relations between elements in the discourse. It means that cohesion is also a semantic organization, which refers to the linguistic 
linkages found in a speech that forms a discourse. Halliday and Hasan further divided the cohesion of meaning into two parts namely grammatically and lexically which had to have cohesion contained in a unified text (Halliday \& Hasan, 1976: 4-6).

In line with the opinion of Halliday and Hasan Richards argues that cohesion is a grammatical and lexical relationship between various different elements in one text that can take the form of relationships between different or different sentences in one sentence (Richards, et al. 2002: 148). Thus cohesion is one of the standards that indicate that a text or discourse is considered communicative, without text cohesion or discourse is not considered communicative.

Halliday and Hassan (1976: 4) suggested that the elements of discourse cohesion can be divided into two types, namely grammatical cohesion, and lexical cohesion. Grammatical cohesion elements consist of reference, substitution, ellipsis, and conjunction. Whereas lexical cohesion consists of synonyms, antonyms, hyponyms, repetition, equivalence.

\subsection{Coherence}

If cohesion is related to the formation of texts, then coherence is an aspect of meaning that refers to aspects of speech or that illustrates how implied propositions can be interpreted and concluded. According to Renkema (2004: 138), coherence is interwoven parts of discourse; semantic cohesiveness that can be achieved by factors outside the discourse. So coherence is the continuity of information.

Coherence refers to how textual components, such as the configuration of concepts and relationships that underlie a text are mutually acceptable and related. In other words, coherence is the understanding of the meaning that is owned by the listener or reader. Because coherence refers to aspects of meaning that require interpretation, coherence can occur implicitly. The coherence of the cohesive element is the inward element (Keraf, 2005: 30).

Brown and Yule said that coherence is the integration of ideas between parts of the discourse, and cohesion is one way to form coherence. Coherence is one important aspect of discourse in supporting the integrity of the meaning of discourse. If a discourse does not have coherence, the semantic-pragmatic relationship that should be non-existent and illogical (Mulyana, 2005: 135).

Brown and Yule (1983: 135) emphasize that coherence means cohesiveness and understanding between units in a text or utterance. In the structure of discourse, the aspect of coherence is very necessary to organize their inner affinity between propositions with each other to get wholeness. The coherent is explained by the existence of relations of meaning that occur between elements in a semantic manner. Semantic relationship means that the relationship occurs between positions. 
Structurally, the relationship is represented by a semantic link between one sentence and another sentence. This meaningful relationship is sometimes marked by lexical devices but sometimes is a sign (Kridalaksana: 2008).

As a semantic connection between the parts of the discourse, coherence consists of two, namely the signified coherence, and the non-signified coherence. The signified coherence is the semantic connection between the parts of the discourse whose expression is marked by conjunction. Whereas the non-signified coherence is the semantic relationship between parts of a discourse that is textually not marked by a conjunction but can be understood from the relations between the elements (Baryadi, 2002: 34).

\section{RESEARCH METHODOLOGY}

This research was descriptive qualitative research. In qualitative research, there are several types of approaches, namely ethnography, case studies, document or text studies, natural observations, centralized interviews, grounded theory, and historical study approaches. This study uses a document or text study approach. The study of documents or texts is an approach that focuses on the analysis or interpretation of written material based on the context. This study uses a document or text study approach because in this study the material under study is a discourse from someone's post on the social media Facebook.

The data of this study were the discourse quotations from someone's post contained on social media Facebook. According to Sugiono (2011: 137), data sources are all things that can provide information about data. Based on the source, data sources can be divided into two kinds, there are primary data sources and secondary data sources. The data of this study were discourse posts from an account on social media Facebook. The primary data source in this study was social media Facebook, while secondary data sources were literature, articles, journals and sites on the internet that are relevant to the research conducted.

The main instrument of this study is the researcher because in this study the researcher is a planner, data collector, and data analyzer. The stages of the study were divided into three stages including (1) the stage of making the research design; (2) the research implementation stage; (3) the research report stage (Arikunto, 2013: 61).

This study examines aspects of cohesion and coherence that exist in the discourse of the story "Layangan Putus". The data used in this study is written data. In this case, the researcher read the whole story "Layangan Putus" and comprehended sentence by sentence in each paragraph. Then the researcher used the note technique and grouped the data into each data group to found aspects that existed in cohesion and coherence.

Indonesian Journal of EFL and Linguistics, 5(1), 2020 
Ani Latifah \& Sulis Triyono

After that, the researcher analyzed the cohesion and coherence of the data obtained by the researcher.

\section{FINDINGS}

Based on data analysis, there were three types of grammatical cohesion in this study, there were reference, substitution, conjunction. From this type of cohesion, there were twenty-seven data in it, namely, six data references, five data substitution, and sixteen data conjunctions. The results of research on grammatical cohesion have shown cohesion in the form of cohesion in this discourse.

Whereas in lexical cohesion, there were three types of lexical cohesion in this study, there were repetition, synonym, and antonym. In grammatical cohesion, it contains eleven data in it, there were two data repetitions, six data synonyms, and three data antonyms. The results of research on lexical cohesion have shown cohesion in the form of cohesion in this discourse. Then for coherence, there were five types of coherence, namely temporal coherence, intensity coherence, contrast coherence, causality coherence, and chronological coherence.

\subsection{Grammatical Cohesion}

\subsubsection{Reference}

Reference is grammatical cohesion in the form of certain lingual units that refer to other lingual units that precede or follow it (Sumarlam, 2003: 24). There are three types of referencing, namely persona referencing, demonstrative referencing and comparative referencing. In this discourse, the type of reference that arises is demonstrative reference which refers to place and time.

Musala memang tak berjarak jauh dari rumah. Hanya terhalang satu rumah dari tempat kami tinggal. Anak-anak sudah biasa berangkat salat dan mengaji sendiri. Ini salah satu yang membuat aku terus berusaha mempertahankan rumah ini.

Aku, 32 tahun, perantauan dari pelosok daerah. Hidup di Bali sudah 14 tahun. Aku menjalani Pendidikan Dokter Hewan di Universitas Negeri Udayana tahun 2004.

Pulang kampung 2011 hanya untuk menikah, kemudian kembali ke Bali karena suamiku bekerja disini.

The word ini, Bali, and sini are demonstrative references to places.

Sekarang dia sudah duduk dikelas 2 sekolah dasar. Tahun lalu dia memang mengambil kelas bahasa inggris dan matematika di kumon. 
Alman anak ketiga ku pulang kerumah setengah jam yang lalu, ia bersemangat menemuiku dan memamerkan hasil tulisan arab nya yang di nilai 90 oleh guru mengajinya.

Suamiku, yang kini sudah resmi menjadi mantan.

These word sekarang, tahun lalu, and yang lalu are demonstrative references of time.

\subsubsection{Substitution}

Substitution is grammatical cohesion in the form of replacing certain lingual units with other lingual units (which have been mentioned) in the discourse to obtain differentiation (Sumarlam: 2003). Based on the type of substitution submitted by Sumarlam (2003), there are two types of substitution that appear in this discourse, there are verbal substitution and noun substitution.

Tetapi hari minggu kemarin, kudampingi dia mengerjakaan $P R$ di buku tematik. Amir terlihat kepayahan dalam menyelesaikan soal matematika.

In the sentence above there is a verbal substitution, namely the replacement of lingual units that are categorized as verbs with other lingual units which are also categorized as verbs on the word "mengerjakan" replaced by the word "menyelesaikan".

Amir terlihat kepayahan dalam menyelesaikan soal matematika. Padahal saat masih belajar di Kumon dia sangat lancar menjawab hitungan sederhana.

Tahun lalu dia memang mengambil kelas bahasa inggris dan matematika di kumon. Namun kami putuskan untuk berhenti mengambil subjek Bahasa inggris karena Amir lebih tertarik belajar di English First.

Iseng aku tawarkan untuk kembali mengambil bimbingan matematika di kumon, dengan catatan berhenti sejenak les di EF, dengan tidak mengambil term selanjutnya.

Abang hari ini belum kumon dulu, mommi kan belum daftar ulang, insya alloh bulan depan ya, doain mommi ada rejeki untuk bayar les kumon nya ya"

The sentences above there is noun substitution, namely the replacement of lingual units that are categorized nouns with other lingual units that are also categorized nouns, there are the word "matematika" replaced with "hitungan sederhana", the word "kelas" replaced with subjek", the word "bimbingan" replaced with "les", and the word "daftar ulang" replaced with "bayar".

\subsubsection{Conjunction}

The conjunction is one of grammatical cohesion that is done by connecting one element to another in the discourse in the form of lingual units of words, clause 
phrases, sentences and paragraphs (Sumarlam: 2003). Sumarlam also divides conjunctions into three groups namely coordinative conjunctions, correlative conjunction, and subordinative conjunction. In this discourse, there were sixteen conjunctions found with various types of conjunctions.

Coordinative Conjunction, the conjunction that connects two or more elements that are of equal importance or have the same status. Conjunction found were dan, tetapi, padahal, tetapi.

Subordinative Conjunction, The conjunction that connects two or more clauses, and that clause does not have the same syntactic status, one of the clauses is a clause. In this type of conjunction, there were several conjunctions found in this discourse, each of which has a different purpose. Conjunction found were seraya, sementara, seketika, setelah, sambil, hingga, kalau, sebab, karena, sehingga, namun, dengan.

\subsection{Lexical Cohesion}

Lexical cohesion is the relationship between elements in discourse semantically (Sumarlam, 2003: 35). The lexical cohesion contained in this discourse is as follows.

\subsubsection{Repetition}

Repetition is a repetition of the lingual unit of sound, syllable, word, or sentence part that is considered important to emphasize in an appropriate context (Sumarlam, 2003: $35)$.

Kami sedang semangat berolahraga agar lebih fit. Hubungan kami bahkan sedang hangat hangatnya. Dan aku sedang hobi mengumpulkan lingerie untuk menyenangkannya.

In the sentence above there is epizeuxis repetition, namely repetition of lingual units of words that are concerned several times in a row (Sumarlam: 2003).

Aku ke Jakarta sekarang! Aku tak peduli jika harus hilang disana! Aku akan mencari mu sampai ketemu!

In the sentence above there is anaphoric repetition, which is the repetition of the lingual unit in the form of the first word or phrase at the end of the next line or sentence (Sumarlam: 2003).

\subsubsection{Synonymy}

The function of the synonym is to establish an equivalent meaning relationship between certain lingual units with other lingual units in a discourse (Sumarlam, 2003: 39). Based on the lingual form in this discourse, there are several kinds of synonymy.

Synonymy clause or sentence with clause or sentence: 
Musala memang tak berjarak jauh dari rumah. Hanya terhalang satu rumah dari tempat kami tinggal.

Synonymy of word with the word:

Lokasi musala yang sangat dekat dari rumah dan rasa kekeluargaan yang sangat erat antar tetangga ditengah keberadaan minoritas kami, menjadikanku sangat nyaman dan betah disini.

Kulipat mukena dan sajadahku, kurapikan tempat tidur kami.

Synonymy of words with phrases or vice versa:

Maafin mommi ya nak, semua tidak akan mudah seperti dulu, kita belum bisa liburan, kemping bersama, membuat api unggun, membakar kayu.. untuk sekarang.

Aku punya Allah untuk bersandar. Aku punya Allah untuk meminta dan memohon.

Synonymy of phrases with phrases:

Daddy mereka boleh saja memutus komunikasi denganku, ibu dari anakanaknya, bersikap acuh dan mencabut segala fasilitas dirumah ini.

\subsubsection{Antonymy}

Antonymy is also called opposition of meaning. Antonymy is another name for objects or other things or lingual units whose meaning is opposite or in opposition to other linguals (Sumarlam, 2003: 40). There are several antonymy that found in this discourse:

Dan siang ini aku mendapat surat cinta dari PLN. Seorang petugas menaruh surat peringatan akan adanya pemutusan sementara aliran listrik bila tidak segera melakukan pembayaran.

Allah yang Maha Baik yang mengatur segala pertemuan dan perpisahan.

Anak anakku akan jadi anak bahagia yang sukses dunia dan akhirat.

\subsection{Temporal Coherence}

According to Sumadi, temporal coherence, namely coherence which states the relationship of time meaning between one sentence with another sentence (Hartanti, 2007: 45).

Aku, 32th, perantauan dari pelosok daerah. Hidup di Bali sudah 14 tahun. Aku menjalani Pendidikan Dokter Hewan di Universitas Negeri Udayana tahun 
Ani Latifah \& Sulis Triyono

2004. Pulang kampung 2011 hanya untuk menikah, kemudian kembali ke bali karena suamiku bekerja disini.

Akhirnya, setelah 12 hari pencarian, dia mengabarkan akan pulang. Mas Arif memintaku menunggu dirumah. Tapi rasa khawatirku memuncak sudah. Aku tidak bisa duduk manis menunggunya di rumah. Segera kupacu mobil menuju bandara. Teringat, 10 hari lalu, aku penuh kebingungan mencarinya, semua kemungkinan berkecamuk di kepalaku.

Aku resmi menjadi janda setelah 8 tahun pernikahan. Walau aku sudah menemaninya dari tahun 2005. Total aku mengenalnya adalah 14 tahun. Pernikahan kami menghasilkan 5 orang anak. Anak bungsuku meninggal saat kulahirkan 4 bulan lalu.

In the example above it appears that there are six sentences. Between these sentences, there is a relationship between the meaning of time stated with "setelah 12 hari, 10 hari lalu, 8 tahun, tahun 2005, 14 tahun, 4 bulan".

\subsection{Intensity Coherence}

Coherence of intensity, namely coherence which states the seriousness or affirmation relationship contained in a number of markers in its function as a liaison between one sentence with another sentence (Sumadi, 2007: 46).

Mas Arif paham, menyentuh lawan jenis adalah haram baginya. Bahkan, menundukan pandangan terhadap wanita non mahrom adalah kewajiban. Aku percaya betul suamiku.Tapi, kemana dia?

The example above consists of four sentences. Among the sentences are the expressions indicated by the conjunction "bahkan".

\subsection{Causality Coherence}

This coherence is stated by the first sentence stating the cause, while the next sentence states the effect. Following is the use of cause-effect relationships in sentences.

Namun kami putuskan untuk berhenti mengambil subjek Bahasa inggris karena Amir lebih tertarik belajar di English First. Lembaga les bahasa asing yang menitik beratkan pada latihan percakapan menggunakan bahasa inggris.

Mushola memang tak berjarak jauh dari rumah. Hanya terhalang satu rumah dari tempat kami tinggal.

Dia senang sekali mendapat hadiah permen dari ustadzah karena sudah berhasil menghapal surah Al Ashr. 
Kemudian aku pindah ke kamar utama kami, karena di sanalah anak anak kami tidur.

Kami sedang semangat berolahraga agar lebih fit. Sehingga Ranjang kami hidup sekali.

In the example above, the last sentence coheres causality with the previous sentence, and the coherence is marked by the conjunction "Karena, sehingga, hanya".

\subsection{Contrast Coherence}

Contrast coherence, namely coherence which states the relationship of contradiction or resistance between one sentence with another sentence.

Anak anak masih belum pulang dari mushola, mereka mengerjakan sholat isya disana. Arya memang tidak pulang sedari magrib tadi, berbeda dengan kakak dan adeknya. Amir dan Alman memilih makan malam selepas magrib di rumah. Sedangkan Arya di hari senin dan kamis terbiasa ikut buka puasa sunnah bersama di mushola.

In the example above, the second sentence coincides with the first sentence marked conjunction "berbeda dengan".

\subsection{Chronological Coherence}

Chronological coherence, namely coherence which states the relationship of time series. This coherence is often shown by conjunctions which state temporally.

Kuarahkan ia ke sofa ruang tamu, ku letakan pelan Arya yang juga mulai terjaga, kemudian ku dekap erat Abi.

Mbi adalah panggilan sayang kami. Aku lupa apa yang menyebabkan kami saling memanggil Mbi. Mungkin dari baby kemudian beralih menjadi Mbi.

[Mbii, aku ke Jakarta sekarang! Aku tak peduli jika harus hilang disana! Aku akan mencari mu sampai ketemu!] Pesanku. Kemudian dibalas.

The sentences in the example above state the various events that occur chronologically as indicated by the elements "kemudian".

\section{DISCUSSION}

The current research has aimed to investigate cohesion and coherence created in a discourse on the story of "Layangan Putus" which some time ago was written by a housewife on Facebook with the account "Mommy Asf". She told the story of her family who was having problems, where her husband betrayed her and divorced her. To spill all her feelings, she spilled it into a post on her Facebook status, because she also has a hobby of writing. Not unexpectedly, it turns out the writing has an appeal 
and sympathy from the people who read it. However, shortly after the story was posted on her Facebook account, she deleted the text and apologized to all readers and thanked those who sympathized and also prayed for her and her children. For this reason, the researcher try to examine the cohesion and coherence of the story.

According to Halliday and Hasan (1976) in their book, explaining that cohesion is a factor that influences showing whether a text is well connected or just a group that is not related to a sentence. Based on these findings, cohesion in the story showed that it has been created through the use of cohesive devices. It showed that the story written by the proprietor of the Facebook account has paid attention to the creation of cohesion. It can be seen from the number of cohesive devices used, including grammatical cohesion and lexical cohesion. The first category includes the use of references, substitutions, and conjunctions. Regarding the use of conjunctions, which often appears in this story are "dan", "karena" for causation, and "kemudian" for temporal conjunctions.

In this study, the writer did not use an ellipsis, as Halliday and Hasan (1976) say which states that ellipsis is a type that is rarely found in narrations or descriptions but is usually present in many example dialog. For the category ellipsis, people are not used to using it ellipsis in a cohesive device. There are still many people who do not understand about ellipsis themselves, let alone to use them. It finding implies that there is still much knowledge about cohesion in writing that is not understood.

Not only in non-academic discourse, in academic discourse such as students' writing, ellipsis was rarely found. As the findings submitted by Ayub et al. (2013) who examined the cohesion and coherence of student writing in the second grade of Senior High School found that references, lexical cohesion, and conjunctions were dominantly used by students because they were considered to be quite easy to apply. Meanwhile, ellipsis and substitution is rarely used in their writing because it is quite difficult to use. Students do not know exactly how, where and when to use it, and they prefer to avoid using it in their writing.

It turns out that students' ability to make cohesive and coherent writing is also influenced by students' first language skills. As research conducted by Leo (2012) to Chinese students who found that the first language (L1) and length of residence (LOR) in Canada also influenced students to make cohesive and coherent writing. Canadianborn Chinese (CBC) students tend to be more able to explore the use of lexical and referential discourse markers compared to students with shorter length of residence (LOR).

As for the coherence of the story made from the ideas of each paragraph that builds narration. This finding is relevant to that conveyed by Wuang, Hui and Sui, Danny (2010) who state conceptual coherence is the consistency of structure and point of 
view which means that an article must focus clearly on them. From the results of data analysis, it can be concluded that the story writer writes a coherent story, where the structure of the text is in line with the genre of the text.

The coherence of the story is also seen from its generic structure. From the findings, the writer of the story showed that the writer used the general generic. In the case of complications, show complications that are simple and complex. That implies that the competence of writers in exploring ideas is already good, especially in exploring varied complications. All of this depends on the level of intelligence, talent, and experience in writing stories.

\section{CONCLUSION}

Based on the results of research and discussion of Cohesion and Coherence of Discourse in the story of "Layangan Putus" on social media Facebook, it found variations in the use of cohesion and coherence. In this study, there are two problems examined, namely cohesion including grammatical cohesion and lexical cohesion, and coherence including temporal coherence, contrast coherence, causal coherence, chronological coherence, and intensity coherence.

From the results mentioned above, the elements of the language used contain cohesion and coherence so that the writing of the story "Layangan Putus" was interrelated between one language element and other language elements. The most common data found is cohesion in the form of conjunction. In some previous studies, many conjunctions have been found because those are used to connect the same two elements in one discourse. It was intended to support the main ideas discussed in the discourse.

\section{REFERENCES}

Aghdam, S. H., \& Hadidi, Yaser. (2015). Cohesion and Coherence in Political Newspapers and Discussion Sections of Academic Articles. International Journal on Studies in English Language and Literature. 3 (3), 2015.

Alwi, Hasan, dkk. (2003). Tata Bahasa Baku Bahasa Indonesia. Jakarta: Balai Pustaka.

Andayani, Pipit Olva et al. (2014). An Analysis of the Cohesion and Coherence of the Students' Narrative Writings in SMP Negeri 2 Banjar. Jurnal Pendidikan Bahasa Inggris Indonesia Universitas Pendidikan Ganesha. 2 (1), 2014.

Arikunto, Suharsimi. (2013). Prosedur Penelitian Suatu Pendekatan Praktik. Jakarta: PT Rineka Cipta.

Ayub, K. Seken, W. Suarnajaya. (2013). An Analysis of the Cohesion and Coherence of Students' English Writings at the Second Grade of SMAN 1 Labuapi West 
Ani Latifah \& Sulis Triyono

Lombok. e-Journal Program Pascasarjana Universitas Pendidikan Ganesha. 1 (1), 2013.

Baryadi, Pratomo. (2002). Dasar-dasar Analisis Wacana dalam bahasa. Yogyakarta: Pustaka Ganda Suli.

Brown, Gillian dan George Yule. (1983). Discourse Analysis. Cambridhe: Cambridge

University Press.

Eriyanto. (2008). Analisis Wacana. Yogyakarta: PT. LkiS Pelangi Aksara.

Halliday, M, A., \& Hasan, R. (1976). Cohesion in English. London: Longman.

Hartanti, Yuanita. (2007). Kohesi dan Koherensi dalam Wacana pada Buku Teks

Bahasa dan Sastra Indonesia SMU kelas X karangan Dawud dkk, terbitan Erlangga 2004. Yogyakarta: USD.

Jorgensen W. Marianne, Louise J. Philips. (2007). Analisis Wacana. Yogyakarta:

Pustaka Belajar.

Keraf, Gorys. (2005). Komposisi. Semarang: Bina Putra.

Kridalaksana, Harimurti. (2008). Kamus Linguistik. Jakarta: PT Gramedia Pustaka Utama.

Leo, Krista. (2012). Investigating Cohesion and Coherence Discourse Strategies of Chinese Students with Varied Lengths of Residence in Canada. TESL Canada Journal/ Reveu TESL Du Canada. 29 (6), 2012.

Moeliono, Anton M. (2004). Tata Bahasa Baku Bahasa Indonesia. Jakarta: Balai Pustaka

Mubarak, Zia Hisni. (2014). An Analysis of Cohesion Devices in Political News of the Jakarta Post: A Discourse Analysis Approach. Jurnal Basis UPB. 1 (2), 2014

Mulyana. (2005). Kajian Wacana: Teori, Metode dan Aplikasi Prinsip-Prinsip Analisis

Wacana. Yogyakarta: Tiara Wacana

Prayudha. (2016). The Cohesion and Coherence of the Editorials in the Jakarta Post. Ahmad Dahlan Journal of English Studies (ADJES). 3 (2), 2016.

Renkema, Jan. (2004). Introduction to Discourse Studies. Amsterdam: John Benjamins Publishing Company

Richards, Jack. (2002). Longman Dictionary of Applied Linguistics. Hong Kong: Longman Group

Sugiyono. (2011). Metode Penelitian Kuantitatif Kualitatif dan R\&D. Bandung: Alfabeta

Sumarlam. (2003). Teori dan Praktik Analisis Wacana. Surakarta: Pustaka Cakra Widiatmoko, Wisnu. (2015). Analisis Kohesi dan Koherensi Wacana Berita Rubrik Nasional di Majalah Online Detik. Jurnal Sastra Indonesia. 4 (1), 2015 